\title{
MACIEJ JABLOŃSKI
}

Instytut Ekologii i Bioetyki, UKSW, Warszawa

\section{Ochrona środowiska przez administrację publiczną w gospodarce morskiej}

Słowa kluczowe: Gospodarka morska, administracja publiczna, bezpieczeństwo morskie, zanieczyszczenia

Keywords: maritime affairs, public administration, maritime security, pollutants

\section{Administracja morska i jej kompetencje}

Jednym z kluczowych dokumentów, które w sposób bezpośredni odnoszą się do bezpieczeństwa ekologicznego w gospodarce morskiej jest ustawa z dnia 21 marca 1991 r. o obszarach morskich Rzeczypospolitej Polskiej i administracji morskiej(A). Wskazany akt prawny określa kompetencje administracji publicznej w całości zagadnień dotyczących jej funkcjonowania, z uwzględnieniem spraw środowiskowych. Ustawa określa m.in. położenie prawne obszarów morskich Rzeczypospolitej Polskiej, pasa nadbrzeżnego oraz organy administracji morskiej i ich kompetencje; natomiast przepisów ustawy nie stosuje się, jeżeli umowa międzynarodowa, której Rzeczpospolita Polska jest stroną, stanowi inaczej. Zgodnie $\mathrm{z}$ normami ustawowymi obszarami morskimi Rzeczypospolitej Polskiej są: morskie wody wewnętrzne, morze terytorialne oraz wyłączna strefa ekonomiczna. W stosunku do określonych enumeratywnie elementów obszarów morskich RP, zwierzchnictwo terytorialne nad morskimi wodami wewnętrznymi i morzem terytorialnym rozciąga się na wody, przestrzeń powietrzną nad tymi wodami oraz na dno morskie wód wewnętrznych i morza terytorialnego, a także na wnętrze ziemi pod nimi. Zadania administracji publicz- 
nej realizowane są w zakresie ochrony środowiska przez zorganizowany system, który stanowi określony przez ustawodawcę ustrój organów administracji morskiej, którymi są: minister właściwy do spraw gospodarki morskiej, jako naczelny organ administracji morskiej oraz dyrektorzy urzędów morskich, jako terenowe organy administracji morskiej. W szczególności do organów administracji morskiej należą m.in. sprawy: bezpieczeństwa żeglugi morskiej; bezpieczeństwa związanego z badaniami, rozpoznawaniem i eksploatacją zasobów mineralnych dna morskiego oraz ochrony środowiska morskiego przed zanieczyszczeniem wskutek korzystania $\mathrm{z}$ morza oraz przez zatapianie odpadów $\mathrm{i}$ innych substancji $\mathrm{w}$ zakresie nieuregulowanym przepisami prawa geologicznego i górniczego. Funkcjonujące organy niezespolonej administracji publicznej, tj. urzędy morskie, funkcjonują w Polsce w liczbie trzech, na podstawie rozporządzenia Ministra Transportu i Gospodarki Morskiej z 7 października 1991 r. w sprawie utworzenia urzędów morskich, określenia ich siedzib oraz terytorialnego zakresu działania dyrektorów urzędów morskich (B).

Dokonując uzgodnienia w trybie art. 37 ust. 3 ustawy o obszarach morskich Rzeczpospolitej Polskiej i administracji morskiej w postępowaniu o uzgodnieniu wycinki drzew Minister Gospodarki Morskiej podjął próbę przeprowadzenia oceny, jakie skutki będzie miało wycięcie spornych drzew, niemniej jednak analizy dokonał w kontekście wpływu planowanego zamierzenia na obszar chronionego krajobrazu pn. „Koszaliński Pas Nadmorski”, w obszarze którego zlokalizowane są działki, na terenie których znajdują się sporne drzewa. Tym samym uznać należy, iż organ ten nie ocenił planowanego zamierzenia przez pryzmat przesłanek wynikających z treści art. 37 ust. 3 w zw. $\mathrm{z}$ art. 36 ust. 2 ustawy, to jest czy wycinka drzew na terenie pasa ochronnego będzie miała negatywny wpływ na stan pasa technicznego i cele jakim on służy (C). Z kolei dyrektorzy urzędów morskich wydają przepisy prawne na podstawie upoważnień udzielonych im w ustawach, a w zakresie nieunormowanym w przepisach, jeżeli jest to niezbędne do ochrony życia, zdrowia lub mienia, ochrony środowiska morskiego na morzu, w porcie morskim, przystani oraz w pasie technicznym, a także ochrony żeglugi i portów morskich dyrektor urzędu morskiego 
może ustanawiać przepisy porządkowe zawierające zakazy lub nakazy określonego zachowania się. W razie konieczności natychmiastowego wprowadzenia w życie zarządzenia porządkowego, może ono być publikowane $\mathrm{w}$ drodze obwieszczeń w miejscach jego obowiązywania, drogą radiową lub w inny sposób zwyczajowo przyjęty w żegludze morskiej lub na danym terenie. Na podstawie upoważnienia ustawowego inspekcja morska ma prawo wykrywania zanieczyszczeń środowiska morskiego powodowanych działalnością na morzu i ich sprawców, kontrolowania, czy statki spełniają wymagania w zakresie ochrony żeglugi morskiej oraz inspekcja bandery ma prawo kontrolowania statków o polskiej przynależności w zakresie wymagań określonych w przepisach prawa polskiego, przepisach prawa Unii Europejskiej oraz w ratyfikowanych umowach międzynarodowych dotyczących ochrony środowiska. Przed wydaniem decyzji nakazującej opuszczenie polskich obszarów morskich przez statek dyrektor urzędu morskiego powinien przeprowadzić postępowanie wyjaśniające w zakresie ustalenia rodzaju i stopnia zanieczyszczenia morza lub zagrożenia zanieczyszczeniem tego rodzaju; ustaleń powinny dokonać osoby posiadające wiadomości specjalne (D). I tak np. armatorowi, $\mathrm{z}$ którego statku podczas przebywania w polskich obszarach morskich dokonuje się, $\mathrm{z}$ naruszeniem przepisów niniejszej ustawy i innych ustaw oraz przepisów wydanych na ich podstawie, zanieczyszczania środowiska morskiego wymierza się karę pieniężną o równowartości do 1.000 .000 jednostek obliczeniowych, zwanych „Specjalnym Prawem Ciągnienia (SDR)”, określanych przez Międzynarodowy Fundusz Walutowy.

Spektrum administracji publicznej z zakresu ochrony środowiska w dziedzinie gospodarki morskiej jest bardzo szerokie, o czym świadczy np. fakt, iż inne działy administracji wdrażają swoje wytyczne w tej dziedzinie. I tak Minister Zdrowia w rozporządzeniu z 21 grudnia 2010 r. w sprawie szczególnych wymagań higienicznych w zakresie transportu morskiego luzem cukru surowego, olejów płynnych i tłuszczów (E), wydanym na podstawie art. 70 ustawy z 25 sierpnia 2006 r. o bezpieczeństwie żywności i żywienia (F), określił wymagania higieniczne w transporcie morskim luzem cukru surowego i płynnych olejów i tłuszczów. Dotyczy to przypadków odstępstw od wymagań określonych 
w rozdziale IV ust. 4 załącznika II do rozporządzenia (WE) nr 852/2004 Parlamentu Europejskiego i Rady z dnia 29 kwietnia 2004 r. w sprawie higieny środków spożywczych (G). Minister Zdrowia wskazał, że transport morski cukru surowego luzem, który nie jest przeznaczony do spożycia przez ludzi i do produkcji żywności bez uprzedniego zastosowania pełnego i efektywnego procesu rafinacji, jest dozwolony w pojemnikach lub kontenerach, które nie są używane wyłącznie do transportu środków spożywczych.

\section{Program ochrony środowiska morskiego}

Każde państwo członkowskie UE opracowuje strategię morską dla swoich wód morskich, w której uwzględniona zostanie specyfika tych wód i która będzie jednocześnie odzwierciedlać ogólne perspektywy danego regionu lub podregionu morskiego $(\mathrm{H})$. Za akt prawny skorelowany z prawem unijnym w ramach prawa krajowego w Polsce należy uznać „Program ochrony brzegów morskich”, obejmujący swoim zakresem przedsięwzięcia mające na celu zabezpieczenie brzegów morskich przed zjawiskiem erozji. Program został określony jako program wieloletni i obejmujący swoim zakresem działania lata 2004-2023. Jego zakres przedmiotowy został wskazany w ustawie z 28 marca 2003 r. o ustanowieniu programu wieloletniego „Program ochrony brzegów morskich” (I). W założonym okresie zdecydowano się podjąć zadania dotyczące:

1) budowy, rozbudowy i utrzymywania systemu zabezpieczenia przeciwpowodziowego terenów nadmorskich, w tym usuwania uszkodzeń w systemie zabezpieczenia przeciwpowodziowego brzegów morskich;

2) zapewnienia stabilizacji linii brzegowej według stanu z 2000 r. i zapobiegania zanikowi plaż;

3) monitorowania brzegów morskich, a także czynności, prac i badań dotyczących ustalenia aktualnego stanu brzegów morskich mających na celu wskazanie koniecznych i niezbędnych działań zmierzających do ratowania brzegów morskich. 
Zgodnie z ustawą z dnia 27 kwietnia 2001 r. Prawo ochrony środowiska (J), pośród całości zagadnień dotyczących bezpieczeństwa ekologicznego w Polsce, jedną z dziedzin dookreślonych normami prawnymi jest gospodarka morska. Pojęta przez ustawę regulacja prawna wskazuje na ochronę środowiska wód morskich i śródlądowych, portów i przystani morskich oraz utrzymania bezpieczeństwa ekologicznego w gospodarce morskiej poprzez utrzymanie właściwego stanu środowiska morskiego. Zatem ochrona środowiska w gospodarce morskiej dotyczy zarówno bezpośrednio morskiego, jak i powiązanej infrastruktury. Dlatego też Prawo ochrony środowiska stanowi, że ochronę przed zanieczyszczeniami powstającymi w związku z eksploatacją dróg, linii kolejowych, linii tramwajowych, lotnisk oraz portów zapewnia się przez stosowanie rozwiązań technicznych ograniczających rozprzestrzenianie zanieczyszczeń oraz w właściwą organizację ruchu. Ustawodawca jednoznacznie podkreśla, że eksploatacja dróg, linii kolejowych, linii tramwajowych, lotnisk oraz portów nie może powodować przekroczenia standardów jakości środowiska, a emisje polegające na:

1) wprowadzaniu gazów lub pyłów do powietrza,

2) wprowadzaniu ścieków do wód lub ziemi,

3) wytwarzaniu odpadów,

4) powodowaniu hałasu,

powstające w związku z eksploatacją drogi, linii kolejowej, linii tramwajowej, lotniska oraz portu, nie mogą powodować przekroczenia standardów jakości środowiska poza terenem, do którego zarządzający tym obiektem ma tytuł prawny.

\section{Kompetencje administracji rządowej}

Minister Środowiska w rozporządzaniu z dnia 16 czerwca 2011 r. w sprawie wymagań w zakresie prowadzenia pomiarów poziomów substancji lub energii w środowisku przez zarządzającego drogą, linią kolejową, linią tramwajową, lotniskiem lub portem (K) wskazał wymagania w zakresie prowadzenia pomiarów poziomów substancji lub 
energii w środowisku przez zarządzającego drogą, linią kolejową, linią tramwajową, lotniskiem lub portem, w tym:

1) przypadki, w których są wymagane ciągłe pomiary poziomów wskazanych energii w środowisku oraz okresowe pomiary poziomów wskazanych substancji lub energii w środowisku;

2) referencyjne metodyki wykonywania pomiarów;

3) kryteria lokalizacji punktów pomiarowych;

4) sposoby ewidencjonowania wyników przeprowadzonych pomiarów. W kolejnym rozporządzeniu Ministra Środowiska z dnia 17 stycznia 2003 r. w sprawie rodzajów wyników pomiarów prowadzonych w związku z eksploatacją dróg, linii kolejowych, linii tramwajowych, lotnisk oraz portów, które powinny być przekazywane właściwym organom ochrony środowiska, oraz terminów i sposobów ich prezentacji (L) zostały określone rodzaje wyników pomiarów prowadzonych w związku z eksploatacją dróg, linii kolejowych, linii tramwajowych, lotnisk oraz portów, które ze względu na szczególne znaczenie dla systematycznej obserwacji zmian stanu środowiska, wynikających z eksploatacji tych obiektów, powinny być przekazywane właściwym organom ochrony środowiska, oraz terminy i sposób ich prezentacji.

Całość legitymacji prawnej dla Ministra Środowiska reguluje rozporządzenie z dnia 14 grudnia 2006 r. w sprawie dróg, linii kolejowych i lotnisk, których eksploatacja może powodować negatywne oddziaływanie akustyczne na znacznych obszarach, dla których jest wymagane sporządzanie map akustycznych, oraz sposobów określania granic terenów objętych tymi mapami (M). Minister Środowiska we wskazanym akcie prawnym określił:

1) drogi, linie kolejowe i lotniska, których eksploatacja może powodować negatywne oddziaływanie akustyczne na znacznych obszarach, dla których jest wymagane sporządzanie map akustycznych;

2) terminy zaliczenia dróg, linii kolejowych i lotnisk do obiektów, których eksploatacja może powodować negatywne oddziaływanie na środowisko;

3) sposoby określania granic terenów objętych mapami. 


\section{Administracja publiczna o charakterze niezespolonym}

Ze względu na rozmiary, jakie w skali globalnej zajmują wody morskie, niezwykle ważnym zagadnieniem pozostaje ochrona zarówno morza, jak i dna morskiego. Jednym z najbardziej istotnych elementów jest zabezpieczenie przed niekorzystnym oddziaływaniem floty morskiej na środowisko morskie. Podniesione kwestie reguluje ustawa z dnia 16 marca 1995 r. o zapobieganiu zanieczyszczaniu morza przez statki (N). Zakres przedmiotowy ustawy dotyczy statków znajdujących się w polskich obszarach morskich oraz statków o polskiej przynależności znajdujących się poza granicami tych obszarów. Jednakże należy zauważyć, iż przepisów ustawy nie stosuje się, jeżeli umowa międzynarodowa, której Rzeczpospolita Polska jest stroną, stanowi inaczej. Przyjęcie takich standardów w tym przypadku wydaje się być logiczne, gdyż międzynarodowe publiczne prawo morskie jest kształtowane w oparciu o zwyczaje i standardy, które kształtowały się na w różnych częściach świata przez wiele stuleci, a niezwykle cenne zagadnienie stanowi tu zwyczaj oraz jego potwierdzenie w prawie stanowionym. Według norm ustawowych statek nie może być używany do żeglugi morskiej lub innej działalności na morzu, jeżeli nie odpowiada wymaganiom w zakresie zapobiegania zanieczyszczaniu morza. Dyrektor urzędu morskiego, który otrzyma wiadomość o zanieczyszczeniu lub zagrożeniu zanieczyszczeniem polskich obszarów morskich jest obowiązany w razie potrzeby zarządzić i podjąć odpowiednie działania (O). Dyrektor właściwego urzędu morskiego może udzielić również, w drodze decyzji, zwolnienia od obowiązku każdorazowego zdawania odpadów i pozostałości ładunkowych przed opuszczeniem portu statkom odbywającym, bez zawijania do innych portów, podróże morskie na stałych liniach żeglugowych między:

1) portem położonym w polskich obszarach morskich a innym portem położonym w obszarze Morza Bałtyckiego lub Morza Północnego;

2) dwoma portami położonymi w polskich obszarach morskich;

3) jednym portem. 


\section{Wnioski de lege lata i de lege ferenda}

Sprawnie i bezpiecznie funkcjonująca gospodarka morska w sposób pozytywny wpływa na funkcjonowanie regionu, państwa oraz gospodarki morskiej w wymiarze globalnym. Tylko efektywne procedury zapewnią bezpieczeństwo ekologiczne w gospodarce morskiej. Przesłanką takiego działania będzie skorelowanie kompetencji administracji rządowej centralnej oraz niezesplonej z działaniami i kompetencjami samorządu terytorialnego. Zwłaszcza, że część portów morskich w Polsce oraz Unii Europejskiej pozostaje skomunalizowana, a zatem zarządzanie tymi portami oraz zapewnienie bezpieczeństwa ekologicznego należy do gospodarzy „małych ojczyzn”, czyli do samorządowej administracji publicznej.

\section{Streszczenie}

Gospodarka morska jest dziedziną, która w sposób istotny wpływa na funkcjonowanie całej gospodarki światowej. Dlatego też tak istotne jest przestrzeganie wysokich standardów w zakresie ochrony środowiska, które muszą być w sposób efektywny realizowane przez administrację publiczną. Tylko takie postępowanie administracji może prowadzić do realizacji zasady odpowiedzialności za wprowadzanie do środowiska morskiego substancji zanieczyszczających.

\section{Bibliografia}

(A) Ustawa z dnia 21 marca 1991 r. o obszarach morskich Rzeczypospolitej Polskiej i administracji morskiej (Dz. U. z 2003 r., Nr 153, poz. 1502 j.t.).

(B) Rozporządzenia Ministra Transportu i Gospodarki Morskiej z dnia 7 października 1991 r. w sprawie utworzenia urzędów morskich, określenia ich siedzib oraz terytorialnego zakresu działania dyrektorów urzędów morskich (Dz. U. z 1991 r., Nr 98, poz. 438).

(C) Wyrok Wojewódzkiego Sądu Administracyjnego w Warszawie z dnia 29 października 2007 r. IV SA/Wa 1676/07.

(D) Wyrok Wojewódzkiego Sądu Administracyjnego w Warszawie z dnia 27 lutego 2008 r. IV SA/Wa 2552/07. 
(E) Rozporządzenia Ministra Zdrowia z dnia 21 grudnia 2010 r. w sprawie szczególnych wymagań higienicznych w zakresie transportu morskiego luzem cukru surowego, olejów płynnych i tłuszczów (Dz. U. z 2010 r., Nr 255, poz. 1718).

(F) Ustawa z dnia 25 sierpnia 2006 r. o bezpieczeństwie żywności i żywienia (Dz. U. z 2010 r. Nr 136, poz. 914, Nr 182, poz. 1228 i Nr 230, poz. 1511).

(G) Rozporządzenie (WE) nr 852/2004 Parlamentu Europejskiego i Rady z dnia 29 kwietnia 2004 r. w sprawie higieny środków spożywczych (Dz. Urz. WE L 139 z 30.04.2004, str. 1; Dz. Urz. UE Polskie wydanie specjalne, rozdz. 13, t. 34, str. $319)$.

(H) Dyrektywa Parlamentu Europejskiego i Rady 2008/56/WE z dnia 17 czerwca 2008 r. ustanawiająca ramy działań Wspólnoty w dziedzinie polityki środowiska morskiego (dyrektywa ramowa w sprawie strategii morskiej) (Dz. U. UE. Z 2008 r., L 164, s. 19).

(I) Ustawa $z$ dnia 28 marca 2003 r. o ustanowieniu programu wieloletniego „Program ochrony brzegów morskich" (Dz. U. z 2003 r., Nr 67, poz. 621).

(J) Ustawa z dnia 27 kwietnia 2001 r. Prawo ochrony środowiska (Dz. U. z 2008 r. Nr 25, poz. 150 j.t.).

(K) Rozporządzanie Ministra Środowiska w z dnia 16 czerwca 2011 r. w sprawie wymagań w zakresie prowadzenia pomiarów poziomów substancji lub energii w środowisku przez zarządzającego drogą, linią kolejową, linią tramwajową, lotniskiem lub portem (Dz. U. z 2011 r., Nr 140, poz. 824).

(L) Rozporządzenie Ministra Środowiska z dnia 17 stycznia 2003 r. w sprawie rodzajów wyników pomiarów prowadzonych w związku z eksploatacją dróg, linii kolejowych, linii tramwajowych, lotnisk oraz portów, które powinny być przekazywane właściwym organom ochrony środowiska, oraz terminów i sposobów ich prezentacji (Dz. U. z 2003, Nr 18, poz. 164).

(M) Rozporządzenie Ministra Środowiska z dnia 14 grudnia 2006 r. w sprawie dróg, linii kolejowych i lotnisk, których eksploatacja może powodować negatywne oddziaływanie akustyczne na znacznych obszarach, dla których jest wymagane sporządzanie map akustycznych, oraz sposobów określania granic terenów objętych tymi mapami (Dz. U. z 2007, Nr 1, poz. 8).

(N) Ustawa z dnia 16 marca 1995 r. o zapobieganiu zanieczyszczaniu morza przez statki (Dz. U. z 2006 r., Nr 99, poz. 692 j.t.).

(O) Wyrok Naczelnego Sądu Administracyjnego w Warszawie z dnia 16 lipca 2009 r. II OSK 1018/08. 


\section{The protection of the environment in maritime management}

\section{SUMMARY}

Maritime economy is a field that has a significant impact on the functioning of the entire global economy. Therefore, it is important to comply with high standards of environmental protection, which must be implemented in an effective way by public administrative bodies. Only in this way can the principle of the responsibility for entering into marine environment pollutants be implemented. 